\title{
Expanded polytetrafluoroethylene and polypropylene in the repairing of abdominal wall defects in Wistar rats. Comparative study ${ }^{1}$
}

\author{
Uso das telas de politetrafluoroetileno e polipropileno no reparo de defeitos da parede \\ abdominal em ratos Wistar. Estudo comparativo
}

\author{
Armando José d'Acampora², Fabrícia Slomski Joli ${ }^{3}$, Ricardo Tramonte ${ }^{4}$ \\ 1. Study performed at Surgical Technique and Experimental Surgery, Federal University of Santa Catarina (UFSC), Brazil. \\ 2. Full Professor, PhD, Surgical Technique and Experimental Surgery, UFSC, Brazil. \\ 3. Resident General Surgery Program, University Hospital, UFSC, Brazil. \\ 4. Associate Professor, PhD, Department of Morphological Sciences, UFSC, Brazil.
}

\begin{abstract}
Purpose: To compare the use of polypropylene and PTFE meshes in the treatment of incisional hernias made experimentally on Wistar rats. Methods: The experiment used 24 Wistar rats divided into three cohorts: C-A (ressection of a segment of abdominal wall), E-A (ressection and placement of PTFEe mesh), E-B (resection and placement of polypropylene mesh). After 28 days, the mesh and the surrounding tissue were removed and submitted to macroscopic analysis (assessment of the abdominal wall for presence of abscess in the surgical wound and/or skin necrosis, and adhesions) as well as microscopic analysis (presence of fibrosis, necrosis and abscess, counting of macrophages, mononuclears and polymorphonuclears). Results: Adhesions and abscesses in the surgical wound were observed more commonly associated to the group treated with PTFEe. The size of the fibrous tissue was greater in the group treated with polypropylene. Cohort E-A showed PTFEe mesh enveloped by organized fine connective tissue. No groups presented necrosis on the site of the insertion. The highest mononuclear inflammatory reaction occurred in association to PTFEe when compared to the control group, but the findings for the polypropylene mesh were also significant when compared to the control group. In the analysis of the results obtained for cohorts E-A and E-B, a minimal occurrence of polymorphonuclears was noticed in both groups, which indicates low tissue reactivity to both materials used in the present experiment. Conclusion: Even with epithelization and proliferation of connective tissue, anchorage between PTFEe and abdominal wall is insufficient, which can result in reherniations.
\end{abstract}

Key words: Hernia. Polytetrafluoroethylene. Hernia, Ventral. Rats.

\section{RESUMO}

Objetivo: Comparar o uso de tela de PTFEe e polipropileno no tratamento de hérnias incisionais produzidas experimentalmente em ratos Wistar. Métodos: 24 ratos Wistar foram distribuídos em três subgrupos: C-A (ressecção de segmento da parede abdominal), E-A (ressecção e colocação de tela de PTFEe), E-B (ressecção e colocação de tela de polipropileno). Após 28 dias, retirou-se a peça e procedeu-se à análise macroscópica (inspeção da parede abdominal, avaliando presença de abscesso na ferida operatória e/ou necrose de pele, e aderências) e microscópica (presença de fibrose, necrose e abscesso, e contagem de macrófagos, mononucleares e polimorfonucleares). Resultados: Aderências e abscesso na ferida operatória foram observados mais intensamente no subgrupo tratado com PTFEe. O tamanho do tecido fibrótico foi mais acentuado no subgrupo tratado com polipropileno. Já o subgrupo E-A apresentou a tela de PTFEe envolvida por tecido conectivo fino organizado. Não houve necrose no local de inserção da prótese em todos os subgrupos. Maior reação inflamatória mononuclear ocorreu com o PTFEe quando comparado com o grupo controle, mas com o uso de polipropileno os achados foram significativos se comparados ao grupo controle. $\mathrm{Na}$ análise dos resultados obtidos com os grupos E-A e E-B verificou-se que houve ocorrência mínima de polimorfonucleares em ambos os grupos de animais analisados, indicando assim uma baixa reatividade tecidual de ambos materiais nestes animais experimentais. Conclusão: Mesmo ocorrendo epitelização e proliferação de tecido conjuntivo, a ancoragem entre o PTFEe e a parede abdominal é insuficiente, o que pode resultar numa maior recorrência de hérnias.

Descritores: Hérnia. Politetrafluoretileno. Hérnia Ventral. Ratos. 


\section{Introduction}

Ventral or incisional hernias may occur due to an alteration in cicatrisation or from excessive tensile stress on a previous incision on the abdominal wall. Incidence reaches $10 \%$ in cases of infected wound and $30 \%$ after dehiscence or resuture. Levels of recurrence after correction may reach $40 \%{ }^{1}$. Loss of abdominal wall following trauma or necrotizing infection may also occur. Obesity may be one of the major predisposing factors. The association of obesity with the potential increase of pulmonary complications and wound infection is constant in the post-operative. Thus, it is recommended that patients reduce body weight, abandon smoking, control diabetes and avoid any medicine that may interfere in the cicatrisation process prior to surgery, in an attempt to diminish possible complications such as infection, dehiscence and sources of tissue weakening which most certainly will lead to hernia formation ${ }^{2}$. Infection is associated with more than half of the cases, followed by chronic obstructive pulmonary disease and incoercible vomiting, in addition to more general factors such as malnutrition, ascites, postoperative hematoma, peritoneal dialysis, pregnancy, sepsis, anemia, uremia, kidney failure, diabetes, use of steroids and chemotherapic drugs. The materials most frequently used for the repair of hernia defects are polypropylene ${ }^{2} \quad$ (Marlex ${ }^{\circledR}$ mesh) and polytetrafluorethylene (PTFE). In regards to the latter, so far only few studies have related it to repairing of abdominal defects. Because it is biologically inert, PTFE has many applications in biology, microbiology, medicine, pharmaceuticals and in the food industry. It is an atoxic, antithrombogenic, unabsorbing membrane which does not seem to be affected by the action of tissue enzymes. Expanded PTFE is a new hybrid type of this material whose characteristics allow an increased endothelization and higher resistance to reactions. Since few studies have been carried out on the treatment of incisional hernias, the present study is meant to contribute bridging this gap, and employes Wistar rats to compare - in a quantitative way, rather than only qualitatively — tissue reaction to PTFE and polypropylene, which are widely used in suturing abdominal walls.

\section{Methods}

The experiment was conducted at the Operative Technique and Experimental Surgery Laboratory of the Surgery Department, Federal University of Santa Catarina (UFSC). This research was approved by Ethical Animal Committee of UFSC. Male rats $(n=24)$ of the Wistar strain, with the same age (180 days) and weighing between 250 and 300 grams were used. The animals $(\mathrm{n}=24)$ were distributed by simple draw into tree cohorts, each with eigth rats as described below:

C-A $(n=8)$ : In this cohort, animals underwent a resection of a segment of abdominal wall muscle with no mesh placement, followed by euthanasia and macroscopic assessment of the abdominal wall, including anterior and posterior faces, 28 days after the resection; pieces were later histologically studied.

E-A ( $\mathrm{n}=8)$ : In this cohort, animals were subjected to resection of a segment of abdominal wall, placement of PTFEe mesh, euthanasia and macroscopic assessment of the abdominal wall, including anterior and posterior faces, 28 days after placement of the mesh; pieces were later histologically studied.

E-B $(n=8)$ : In this cohort, animals were subjected to resection of a segment of abdominal wall, placement of a polypropylene mesh, euthanasia and macroscopic assessment of the abdominal wall, including anterior and posterior faces, 28 days after placement of the mesh; pieces were later histologically studied.

Before surgery, animals underwent general anesthesia with a solution of Ketamine hydrochloride (Ketalarâ) and hydrochloride 2-(2.6 xylidine)-5.6-dyhidro-4H-1.3-thiazine (Rompumâ), in the doses of $90 \mathrm{mg} / \mathrm{kg}$ and $10 \mathrm{mg} / \mathrm{kg}$, respectively, with intramuscular application on the inner side of the left thigh. After reaching anesthetic state, animals were positioned horizontally in dorsal decubitus on a $30 \times 35 \mathrm{~cm}$ wooden plank, had their hair shaved on the anterior wall of the abdomen; antisepsis was carried out with a solution of alcohol and iodine $2 \%$. A fenestrated drape was placed $\left(5 \mathrm{~cm}^{2}\right.$ fenestration) on the surgical site to delimit surgical field. With a Metzenbaum scissors, a median incision on the skin was performed supra and infra-umbilical (approximately $2 \mathrm{~cm}$ ), with a resection of approximately $1,5 \times 2 \mathrm{~cm}$ of the wall muscle fragment, thus creating a local defect (Figure 1).

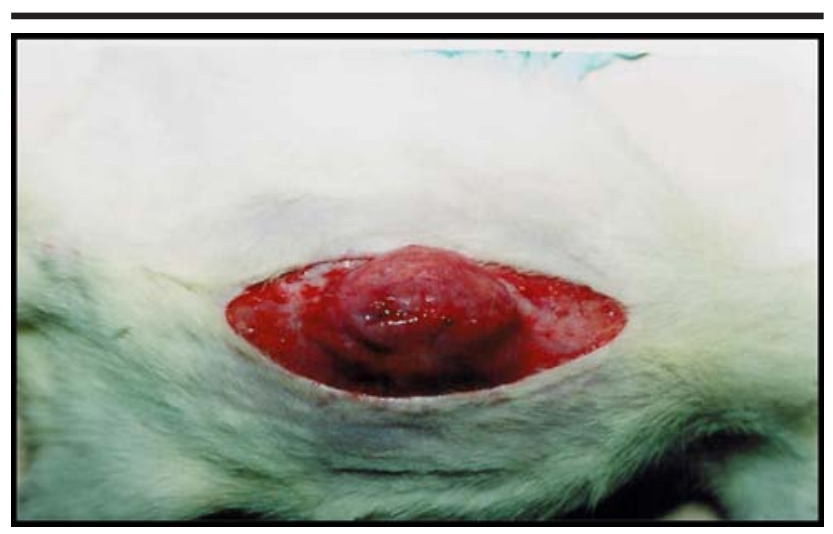

FIGURE 1 - Skin opening showing incisional hernia.

Later, for cohort E-A, approximately 2 x 2,5cm of PTFEe mesh was place on the site of the defect, borders were stitched with simple suture using 5-0 polypropylene thread. Skin closure was performed with simple suture using (Mononylonâ 4-0) unabsorbing thread. The same procedure was carried out for cohort E-B. The utilized mesh in this cohort, however, was polypropylene - Marlex. At the end of the waiting time for each cohort, animals underwent anesthesia for the removal of the pieces corresponding to the repaired defect. Previously, skin condition on the abdominal wall of the rats were assessed to verify the integrity of the surgical wound and the presence or absence of skin abscess or necrosis. The skin was re-incised on the same site of the primary incision, this time however, in a $5 \mathrm{~cm}$ cranial caudal plane. Approximately $5 \mathrm{~cm}^{2}$ of abdominal wall was removed, starting the incision at $2.5 \mathrm{~cm}$ infra-umbilical, in a transversal path to both sides, each extending $2.5 \mathrm{~cm}$. Then a caudal-cranial (inverted $U$ ) incision was performed ending at the upper part, in a transversal manner. For cohort C-A, hernia pouch was opened and the abdominal wall was removed in the same quantity as in other cohorts. Before the total excision of the pieces, possible adhesions on the posterior face were assessed. The adhesions to other walls and structures were not undone; the isolation of the piece was performed through 
distant dissection of the wall in order to preserve adhesions for later analysis. After the piece was isolated, the posterior face was turned to the observer in order to check for adhesions, this face was divided into four quadrants (left upper - LUQ, right upper-RUQ, left lower-LLQ, right lower-RLQ) with the findings being macroscopically described for each analyzed quadrant. Later, the LUQ of the animal was isolated by resection, containing at least $1 \mathrm{~cm}$ of tissue covering the PTFE or polypropylene mesh and $1 \mathrm{~cm}$ of tissue free of the mesh. For the animals in cohort $\mathrm{C}-\mathrm{A}$, a $2 \mathrm{~cm}$ portion was removed median transversal to the muscle resection performed in the surgery. These pieces were then fixed on Whatman paper (\#1) to keep them stretched and immediately placed in a fixing formaldehyde (10\%) solution for 24 hours. The specimens were numbered and embedded in paraffin before being cut transversally (5mm in thickness) with a clearance of $100 \mathrm{~mm}$ between cuts and stained with hematoxylin and eosin (H.E) for routine histological analysis. Ten cuts were obtained from each analyzed specimen, with three cuts of each block being used for morphometric measurements. An area of $100 \mathrm{u}^{2}$, containing part of the mesh and newformed tissue, was determined and assessed for the following: presence of fibrosis, presence of granulomatous tissue and/or tissue necrosis, general state of the tissue along the employed mesh, presence of collagen

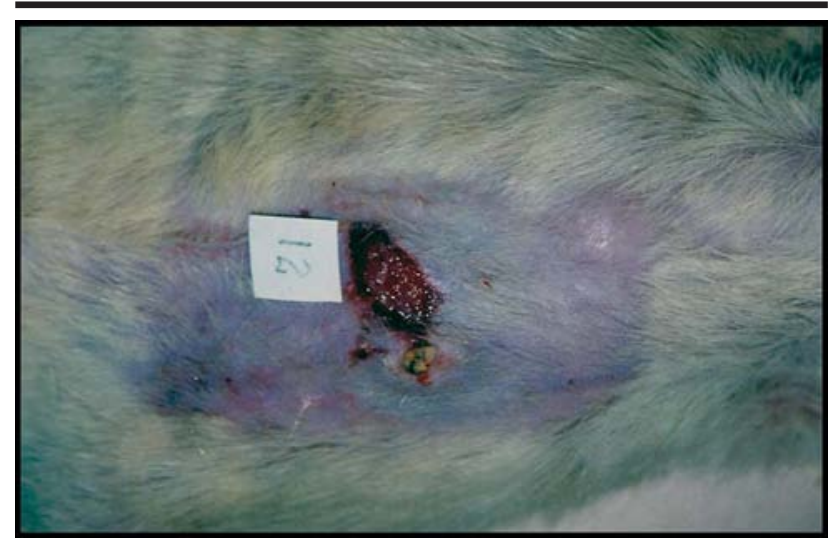

FIGURE 2 - Animal of cohort E-A with abscess and great necrosis of the skin

TABLE 1 - Percentage of adhesions in each quadrant and their quality in cohorts C-A, E-A and E-B

\begin{tabular}{cccl}
\hline COHORT & QUADRANT & \% PRESENCE & \% QUALITY \\
\hline C-A & ULQ & $75 \%$ & $100 \%$ OMENTUM \\
\hline C-A & URQ & $87,5 \%$ & $100 \%$ OMENTUM \\
\hline C-A & LLQ & $62,5 \%$ & $100 \%$ OMENTUM \\
\hline C-A & LRQ & $100 \%$ & $100 \%$ OMENTUM \\
\hline E-A & ULQ & $75 \%$ & $100 \%$ OMENTUM \\
\hline E-A & URQ & $87,5 \%$ & $85,7 \%$ OMENTUM \\
& & & $14,2 \%$ LIVER+ OMENTUM \\
\hline E-A & LLQ & $100 \%$ & $100 \%$ OMENTUM \\
\hline E-A & LRQ & $! 00 \%$ & $75 \%$ OMENTUM \\
& & & $25 \%$ LIVER+ OMENTUM \\
\hline E-B & ULQ & $62,5 \%$ & $80 \%$ OMENTUM \\
& & & $20 \%$ LIVER+ OMENTUM \\
\hline E-B & URQ & $62,5 \%$ & $100 \%$ OMENTUM \\
\hline E-B & LLQ & $75 \%$ & $100 \%$ OMENTUM \\
\hline E-B & LRQ & $75 \%$ & $100 \%$ OMENTUM
\end{tabular}

fibers adhered to the mesh and quantity of foreign body giant cells (and associated macrophages) and quantity of mononuclears and polymorphonuclears. Counts and measurements were carried out by two different observers; neither knew to which cohort the analyzed slide belonged to. Next, the mean of the values obtained by each observer for each of the five analyzed cuts was calculated. Results thus obtained were subjected to statistic analysis (ANOVA - $\alpha \leq$ $0,05)$ to assess quantitatively the possible differences observed among the three cohorts of animals analyzed in the study. Under these procedures, it was possible to study the alterations taking place in the tissue in response to PTFEe and polypropylene.

\section{Results}

Death rate among animals used in the experiment was zero. All animals evolved without intercurrences. Comparisons among all cohorts show lower quadrants to be the most affected, especially the right one. When comparing cohort E-B with cohort E-A, the latter had a higher incidence of adhesion. In all animals of this cohort, adhesions to the lower quadrants were found.

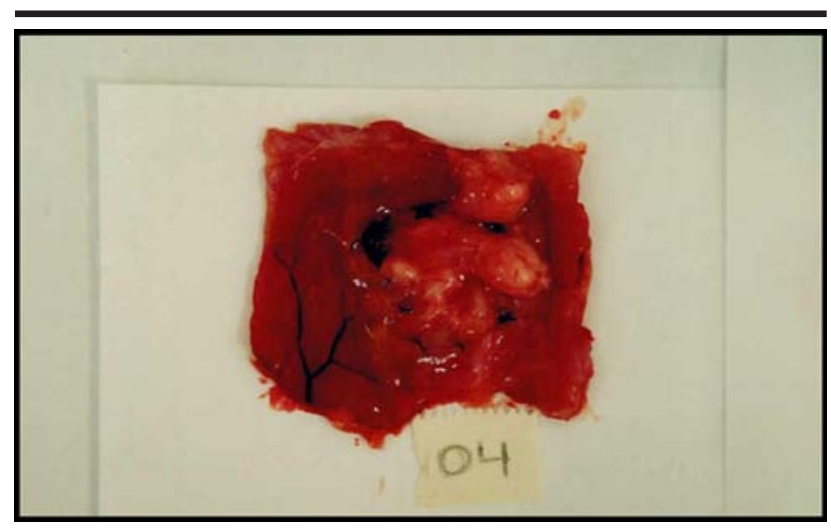

FIGURE 3 - Posterior sight of abdominal wall of animal in cohort E-B, where adhesion to all quadrants can be seen 
TABLE 2 - Presence or absence of skin necrosis in cohorts C-A, E-A, E-B

\begin{tabular}{clccc}
\hline COHORT & PRESENCE & ABSENCE & TOTAL $\%$ & PRESENCE \\
\hline C-A & 0 & 8 & 8 & 0 \\
\hline E-A & 4 & 4 & 8 & 50 \\
\hline E-B & 4 & 4 & 8 & 50 \\
\hline TOTAL & 8 & 16 & 24 & 33,3 \\
\hline
\end{tabular}

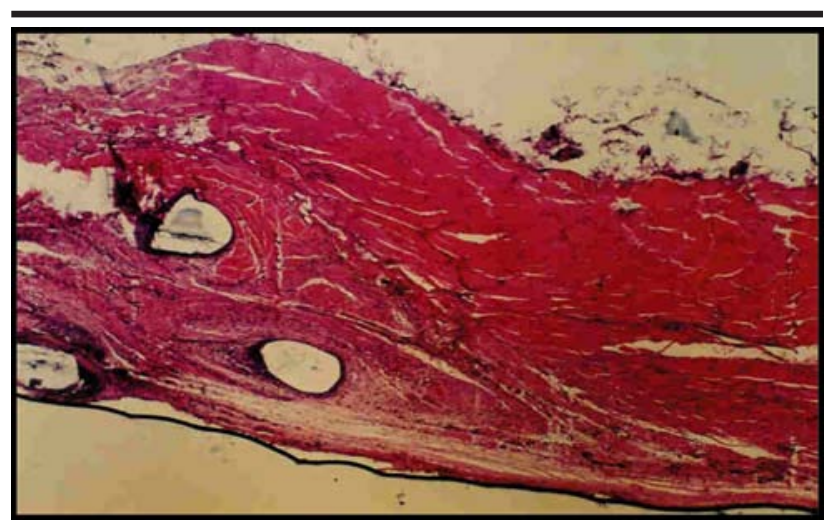

FIGURE 4 - Photomicrography of histological cut of animal in cohort E-B (10x magnification), showing the site of the junction between muscle and newformed fibrous tissue. H.E. staining

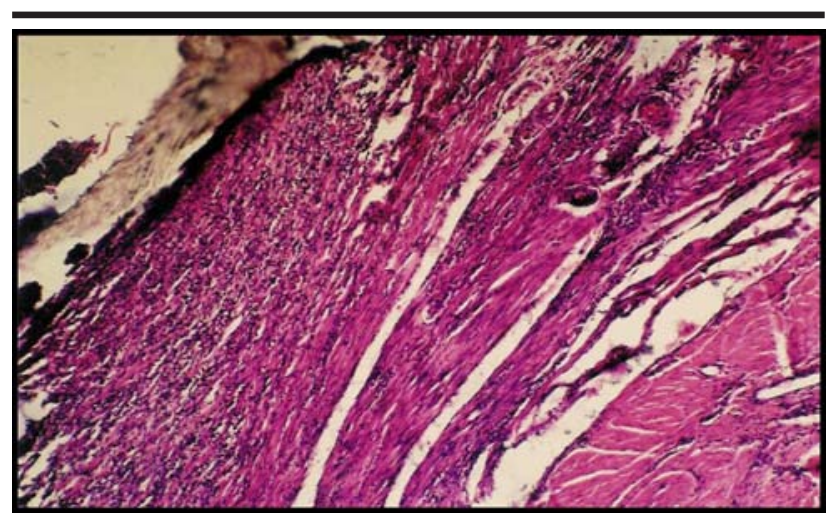

FIGURE 5 - Photomicrography of histological cut of animal in cohort E-A, showing part of the mesh and granulation tissue formed along the muscle of the abdominal wall of the rat $(10 x$ magnification). H.E. staining

TABLE 3 - Mean of measure and counting of microscopic findings in cohort C-A, in three different cuts of the same specimen, under 10 and 40x magnification, carried out by two different observers

\begin{tabular}{|c|c|c|c|c|c|c|}
\hline $\begin{array}{l}\text { ANIMAL } \\
\#\end{array}$ & $\begin{array}{c}\text { FIBROSIS } \\
\text { IN } \mu m^{2} \\
(10 X)\end{array}$ & $\begin{array}{c}\text { NECROSIS } \\
(10 X)\end{array}$ & $\begin{array}{c}A B S C E S S \\
(10 X)\end{array}$ & $\begin{array}{c}\text { GIANT CELL } \\
\text { AND } \\
\text { MACROPHAG } \\
\text { EIN } 100 \mu \mathrm{m}^{2} \\
(40 \mathrm{X})\end{array}$ & $\begin{array}{c}\text { MONONUCIN } \\
I N 100 \mu m^{2} \\
(40 \mathrm{X})\end{array}$ & $\begin{array}{c}\text { POLYMORPIN } \\
\text { IN } 100 \mu m^{2} \\
(40 \mathrm{X})\end{array}$ \\
\hline
\end{tabular}

\begin{tabular}{lllllll}
\hline 1 & 10 & 0 & 1 & 15 & 9 & 0 \\
\hline 7 & 18 & 0 & 0 & 6 & 36 & 1 \\
\hline 8 & 0 & 0 & 0 & 0 & 25 & 0 \\
\hline 19 & 3 & 0 & 0 & 0 & 15 & 0 \\
\hline 21 & 0 & 0 & 0 & 0 & 8 & 0 \\
\hline 22 & 0 & 0 & 0 & 0 & 9 & 0 \\
\hline 23 & 10 & 0 & 0 & 8 & 16 & 0 \\
\hline 24 & 0 & 0 & 0 & 8 & 0 \\
\hline
\end{tabular}




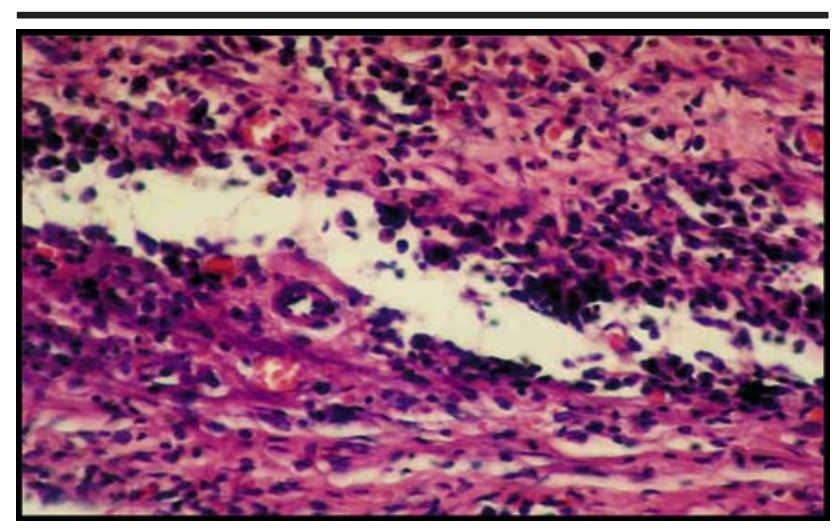

FIGURE 6 - Photomicrography of a counting area (animal in cohort E-A), along granulation tissue formed next to the mesh, indicating the several cell types observed (40x magnification). H.E. staining

TABLE 4 - Mean of measurement and counting of microscopic finding of three cuts, in each animal of cohort E-A, under 10 and 40x magnification

\begin{tabular}{ccccccc}
\hline ANIMAL \# & $\begin{array}{c}\text { FIBROSIS } \\
\text { IN } \mu \mathrm{m} 2 \\
(10 X)\end{array}$ & $\begin{array}{c}\text { NECROSIS } \\
(10 \mathrm{X})\end{array}$ & $\begin{array}{c}\text { ABSCESS } \\
(10 \mathrm{X})\end{array}$ & $\begin{array}{c}\text { GIANTCELL } \\
\text { MACROPHAGE } \\
\text { IN } 100 \mu \mathrm{m}^{2}(40 X)\end{array}$ & $\begin{array}{c}\text { MONONUCIN } \\
\text { IN } 100 \mu \mathrm{m}^{2} \\
(40 X)\end{array}$ & $\begin{array}{c}\text { POLYMORPHIN } \\
\text { IN } 100 \mu \mathrm{m}^{2} \\
(40 \mathrm{X})\end{array}$ \\
\hline 3 & 24,3 & 0 & 7 & 6 & 34 & 0 \\
\hline 5 & 28,3 & 0 & 4 & 1 & 52 & 0 \\
\hline 10 & 50 & 0 & 0 & 4 & 61 & 0 \\
\hline 12 & 50 & 0 & 0 & 2 & 41 & 0 \\
\hline 14 & 70 & 0 & 0 & 9 & 65 & 1 \\
\hline 15 & 50 & 0 & 0 & 1 & 21 & 1 \\
\hline 18 & 30 & 0 & 0 & 0 & 65 & 0 \\
\hline 20 & 40 & 0 & 4 & 0 & & \\
\hline
\end{tabular}

TABLE 5 - Mean of measurement and counting of microscopic findings of three cuts, in each animal of cohort E-B, under 10 and 40x magnification

\begin{tabular}{ccccccc}
\hline ANIMAL \# & $\begin{array}{c}\text { FIBROSIS } \\
\text { IN } \mu m^{2} \\
(10 X)\end{array}$ & $\begin{array}{c}\text { NECROSIS } \\
(10 X)\end{array}$ & $\begin{array}{c}\text { ABSCESS } \\
(10 X)\end{array}$ & $\begin{array}{c}\text { GIANTCELL } \\
\text { MACROPHAGE } \\
\text { IN } 100 \mu \mathrm{m}^{2}(40 X)\end{array}$ & $\begin{array}{c}\text { MONONUC-IN } \\
\text { IN } 100 \mu \mathrm{m}^{2} \\
(40 X)\end{array}$ & $\begin{array}{c}\text { POLYMORPHIN } \\
\text { IN } 100 \mu \mathrm{m}^{2} \\
(40 X)\end{array}$ \\
\hline 2 & 9 & 0 & 4 & 6 & 23 & 2 \\
\hline 4 & 7 & 0 & 0 & 6 & 29 & 0 \\
\hline 6 & 8 & 0 & 3 & 2 & 18 & 0 \\
\hline 9 & 14 & 0 & 3 & 2 & 40 & 0 \\
\hline 11 & 34 & 0 & 2 & 2 & 27 & 0 \\
\hline 13 & 17 & 0 & 0 & 2 & 41 & 0 \\
\hline 16 & 8 & 0 & 0 & 0 & 41 & 0 \\
\hline 17 & 20 & 0 & 2 & 1 & & 21 \\
\hline
\end{tabular}


TABLE 6 - Results of the P calculation (comparing the diverse parameters that were analyzed after surgical repair of incisional hernia on abdominal wall of rats) through ANOVA statistic test, showing statistic significance and fixing at 0,05 the nullity hypothesis rejection level

\begin{tabular}{lll}
\hline $\begin{array}{l}\text { PARAMETERS UNDER } \\
\text { AVALUATION }\end{array}$ & COMPARED COHORTS & $\begin{array}{l}\text { RESULT OF P } \\
\text { CALCULATION }\end{array}$ \\
\hline FIBROSIS & C-A, E-A & 1,65 \\
& C-A, E-B & 0,033 \\
NECROSIS & C-A, E-A & - \\
ABSCESS & C-A, E-B & - \\
GIANTCELLSOR & C-A, E-A & 0,09 \\
MACROPHAGES & C-A, E-B & 0,013 \\
MONONUCLEARS & C-A, E-A & 0,45 \\
POLYMORPHONUCLEARS & C-A, E-B & 0,36 \\
& C-A, E-A & 0,45 \\
& C-A, E-B & 0,36 \\
& C-A, E-B & 0,27 \\
\hline
\end{tabular}

\section{Discussion}

The demand of enough tissue for the closure of abdominal hernias and trauma to the abdominal wall requires the insertion of synthetic material. This leads to the quest of finding adequate fascial replacements. The use of biomaterial for repairing incisional hernia reduces markedly the likelihood of recurrence. Disadvantages of prosthesis are related to infection, exuberant growth of granulation tissue, incomplete epithetization, adhesion between viscera and the synthetic mesh ${ }^{2}$, and restrictions to abdominal mobility. Polypropylene is currently the most used synthetic material for the repair of incisional hernia, although propensity to induce extensive visceral adhesion and skin or bowel erosion is documented ${ }^{3}$. PTFEe, also widely used in abdominal reconstruction, possess better mechanical properties and reports of low infection ${ }^{3}$. Actually, tissue reactions and other complications involving the use of these two materials have never been well defined ${ }^{4}$; contradictory reports are to be found in the literature. Adhesion formation between viscera and the mesh is almost inevitable following incisional hernia repair with synthetic material. These adhesions may lead to intestinal obstruction and formation of enterocutaneous fistula, rendering additional laparotomies extremely difficult. A formação de aderências entre víscera e tela é quase inevitável após o reparo de hérnia incisional com materiais sintéticos. Essas aderências podem levar à obstrução intestinal e formação de fístula enterocutânea e tornar laparotomias adicionais extremamente difíceis. Most authors claim that the occurrence of adhesions increase with the use of polypropylene $e^{2,5,6,7,8}$, and that with increased time there is an increase in the occurrence of intestinal adhesion ${ }^{5}$ Bellon ${ }^{9}$ reports a high degree of adhesions with polypropylene and loose adhesions with PTFEe. According to Hengirmen ${ }^{10}$, adhesion became moderate and in the same proportion between the two meshes. For Jenkins ${ }^{11}$, adhesions went from moderate to maximal, both at all time frames, with no difference in waiting times. Adhesion results evidenced a higher incidence in cohort E-A (where PTFEe mesh was used), with a mean value of $90,6 \%$. Cohort E-B (polypropylene) showed a mean value for adhesions of $68,7 \%$. Among all groups, the lower quadrant is the most affected - of which the right one in a greater proportion ( Table 1). Some authors report an equal proportion in the levels of infection ${ }^{7,10}$. Brown ${ }^{4}$ states that PTFEe may be associated to less problems in the presence of infection when compared to polypropylene. On the other hand, Bleichrodt ${ }^{3}$ evidenced increased infection of the wall with the use of PTFEe. Abscesso of the surgical wound was noticed at a higher percentage $(87,5 \%)$ in the cohort treated with PTFEe. It is supposed that this is due to the fact that PTFEe mesh does not have big enough fenestrations as found on the polypropylene mesh, which alloes a more adequate draining. The occurrence of skin necrosis, observed macroscopically, was the same in both cohorts $(50 \%)$ ( Table 2$)$. The present study did not observe the occurrence of necrosis on the mesh insertion site, as seen in tables 3 to 5 . The observation that the polypropylene mesh becomes intensively covered by dense fibrotic tissue and the PTFE mesh enveloped by a capsule of fine connective tissue has been described by several authors ${ }^{5,8,12,13}$. Thus, there seems to be an insufficient anchoring of the PTFEe mesh to the fascia, resulting in an increased recurrence of hernia ${ }^{8}$ In regards to the size of fibrotic tissue, a higher incidence was found in cohort E-B. During slide analysis, it was noticed that in some aninals the mesh had been totally enveloped by highly vascularized, unorganized, dense fibrotic connective tissue, showing a full integration to the repairing tissue. Specimens corresponding to cohort E-A, showed the PTFEe mesh enveloped by organized, fine connective tissue with fibers running in parallel to the surface of the material. Analyzing the presence of mononuclears, in both cases, a higher incidence in the samples treated with PTFEe was noticed. This contradicts some reports in the literature which claim a less active activity occurred with PTFEe ${ }^{7}$. However, in the cohort treated with polypropylene, findings were also significant when compared to the controlled group. Analyzing the specific presence of macrophages, it was noticed that results were practically the same for both materials. Bellon ${ }^{5}$ states that macrophagic reaction does not determine the success or failure rate of either material. As to polymorphonuclears, a minimal occurrence of this kind 
of cell was noticed, not being of any statistic significance when compared to animals in the control group. This shows that tissue defense reaction to these materials stems basically from the lymphocytic strain (mononuclears). This happens due to the fact that a chronic inflammatory reaction was provoked, which is characterized by mononuclear cell infiltration, including macrophages, lymphocytes, and plasmacyte, and reflects a persistent reaction to the aggression; tissue destruction, largely induced by cell inflammation; attempts at repairing by means of connective tissue replacement - i.e., proliferation of small blood vessels and fibrosis (Figure 6).

\section{Conclusions}

1. Adhesions occurr more frequently in animals treated with PTFEe.

2. The lower quadrants of the abdominal wall are the most affected, of which the right one stands out.

3. Abscess of the surgical wound is noticed to a higher proportion in the cohort using PTFEe is used.

4. Fibrotic tissue is more exuberant when polypropylene

5. Presence of chronic inflammation is more pronounced with the use of PTFEe, but is also significant with polypropylene.

\section{References}

1. Tsui S, Ellis H. Healing of abdominal incisional Hernia in infant rats. Br J Surg. 1991;78 (8): 927-9.

2. Beck RT, Reggiani CPD, Soares FB, Baggio RNG, Murata MK, Villavicencio CAM, Sfendrych RR, Francisco JF. Avaliação dos efeitos da membrana cirúrgica de polímero de tetrafluoroetileno na prevenção de aderências: estudo experimental em ratos. Arq Cat Med. 2000; 29 (1-4): 14-7.

3. Bleichrodt RP, Simmermacher RK, van der Lei B, Shakenraad JM. Expanded polytetrafluoroethylene patch versus polypropilene mesh for repair of contaminated defects of the abdominal wall. Surg Gynecol Obstet. 1993; 176(1):18-24.

4. Brown GL, Richardson JD, Malangoni MA, Tobin GR, Ackerman D, Polk HC Jr. comparison of prosthetic materials for abdominal wall reconstruction in the presence of contamination and infection. Ann Surg. 1985; 201(6): 705-11.

5. Bellon JM, Bujan J, Contreras LA, Carrera- San Martín A, Jurado F. Comparison of a new type of polytetrafluoroethylene patch (Mycro Mesh) and polypropilene prótesis (Marlex) for repair of abdominal wall defects. J Am Coll Surg. 1996; 183(1): 11-8.

6. Murphy JL, Freeman JB, Dione PG. Comparison of Marlex and Gore-tex to repair abdominal wall defects in the rat. Can J Surg. 1989; 32 (4): 244-7.

7. Sahin M, Hasanoglu A, Erbilen M, Orakci V, Bulbuloglu E, Ertas E. Comparison of prosthetic materials used for abdominal wall defects or hernias (an experimental study. Acta Chir Hung. 1995-96; 35 (3-4): 291-5.

8. Simmermacher RK, Schakenraad JM, Bleichrodt RP. Reherniation after repair of the abdominal wall expanded polytetrafluoroethylene. J Am Coll Surg. 1994; 178 (6): 613-6.

9. Bellon JM, Bujan J, Contreras LA, Carrera- San Martín A. The use of biomaterials in the repair of abdominal wall defects: a comparative study betweenpolypropylene meshes (Marlex) and a new polytetrafluoroethylene prosthesis (Dual Mesh).J Biomater Appl. 1997; 12(2):121.

10. Hengirmen S, Cete M, Soran A, Aksoy F, Sencer H, Olcay E.Comparison of meshes for the repair of experimental abdominal wall defects. J Invest Surg. 1998; 11(5): 315-25.

11. Jenkins SD, Klamer TW, Parteka JJ, Condon RE. A comparison of prosthetic materials used to repair abdominal wall defects. Surgery. 1983; 94 (2): 392-8.

12. Bellon JM, Bujan j, Contrera L, Hernando A. Integration of biomaterials implanted into abdominal wall: process of scar formation and macrophage response. Biomaterials. 1995; 16(5): 381-7.

13. Bellon JM, Contreras LA, Bujan J, Pascual G, CarreraSan Martin A. Effect of ralaparotomy through previously integrated polypropylene and polytetrafluoroethylene experimental implants in the abdominal wall. J Am Coll Surg. 1999; 188(5): 466-72.

14. Voyles CR, Richardson JD, Bland KI, Tobin GR, Flint LM,Polk HC. Emergency abdominal wall reconstruction with polypropilne mesh. Ann Surg. 1981; 194:219-23.

\author{
Correspondence: \\ Armando José d'Acampora \\ Condomínio San Diego, casa 9 \\ 88024-420 Florianópolis - SC Brazil \\ Phone: (55 48) 9961-0316 \\ dacampora@gmail.com
}

Conflict of interest: none Financial source: none

Received: July 08, 2006

Review: August 16, 2006 Accepted: September 20, 2006

\section{How to cite this article:}

d'Acampora AJ, Joli FS, Tramonte R. Expanded polytetrafluoroethylene and polypropylene in the repairing of abdominal wall defects in Wistar rats: comparative study. Acta Cir Bras. [serial on the Internet] 2006 Nov-Dec;21(6). Available from URL: http://www.scielo.br/acb. 